\title{
IMPLEMENTASI MODEL PEMBELAJARAN MISSOURI MATHEMATICS PROJECT DALAM PEMBELAJARAN MATEMATIKA
}

\author{
Implementation of the Missouri Mathematics Project Learning Model \\ in Mathematics Learning
}

\author{
Yunita Indah Permata Sari ${ }^{1)}$, Salim $^{2)}$ \\ ${ }^{1}$ Jurusan Pendidikan Matematika, Universitas Halu Oleo, Kota Kendari, Sulawesi Tenggara, \\ nafisasiti53@gmail.com \\ ${ }^{2}$ Jurusan Pendidikan Matematika, Universitas Halu Oleo, Kota Kendari, Sulawesi Tenggara, \\ salimpsa@gmail.com
}

\begin{abstract}
The purpose of this study is to examine the Missouri Mathematics Project (MMP) learning model that influences students' mathematical problem solving abilities. This research is a quantitative research using a quasi-experimental approach. The quasi-experimental design used is a posttest-only control group design. The research sample was taken by purposive sampling technique in order to obtain two class groups with different treatments. To obtain data in this study, the instrument of student learning activity sheets and test questions of students' mathematical problem solving abilities was used. The data analysis techniques used consisted of descriptive statistical analysis and inferential statistical analysis. The results of this study reveals that there is significant effect of the MMP learning model on students' mathematical problem solving abilities as indicated by the achievements: (1) student learning activities with the MMP model carried out both by teachers and students are in the very good and good category; (2) the mathematical problem solving ability of students who were treated with the MMP model was 71.60 higher on average compared to students who were treated with the conventional learning model of 35.48; (3) the mathematical problem solving ability of students who were treated with the MMP model was better than students who were treated with the conventional learning model.
\end{abstract}

Keywords: problem solving ability; MMP; math learning.

\begin{abstract}
ABSTRAK
Tujuan penelitian ini yaitu untuk mengkaji model pembelajaran Missouri Mathematics Project (MMP) berpengaruh terhadap kemampuan pemecahan masalah matematis siswa. Penelitian ini merupakan penelitian kuantitatif dengan menggunakan pendekatan quasi experimental. Desain quasi experimental yang digunakan yaitu posttest-only control group design. Sampel penelitian diambil dengan teknik purposive sampling sehingga diperoleh dua kelompok kelas dengan perlakuan yang berbeda. Untuk memperoleh data dalam penelitian ini menggunakan instrumen lembar aktivitas belajar siswa dan soal tes kemampuan pemecahan masalah matematika siswa dengan teknik analisis data yang digunakan terdiri dari analisis statistik deskriptif dan analisis statistik inferensial. Hasil penelitian ini diperoleh informasi bahwa secara signifikan, ada pengaruh model pembelajaran MMP terhadap kemampuan pemecahan masalah matematis siswa yang ditunjukkan dengan capaian: (1) aktivitas pembelajaran siswa dengan model MMP baik yang dilakukan oleh guru maupun siswa berada pada kategori sangat baik dan baik; (2) kemampuan pemecahan masalah matematis siswa yang diberi perlakuan model MMP yaitu 71,60 lebih tinggi rata-ratanya dibandingkan dengan siswa yang diberi perlakuan model pembelajaran konvensional sebesar 35,48; (3) kemampuan pemecahan masalah matematis siswa yang diberi perlakuan model MMP lebih baik dari siswa yang diberi perlakuan model pembelajaran konvensional.
\end{abstract}

Kata kunci: kemampuan pemecahan masalah; MMP; pembelajaran matematika.

\section{PENDAHULUAN}

Pendidikan saat sekarang ini sangat diperlukan bangsa Indonesia untuk meningkatkan kualitas mutu lulusan anak didik sehingga mampu memecahkan secara bersama persoalan bangsa dan negara ke arah yang lebih baik (Sari, Nurhayati, \& Salim, 2019). Upaya pemerintah dalam mengembangkan mutu pendidikan Indonesia salah satunya yaitu adanya perubahan kurikulum. Pelaksanaan 
Kurikulum 2013 pada saat ini, selain penekanannya lebih pada peningkatan nilai-nilai budaya bangsa dan pendidikan karakter, tetapi peningkatan aspek kognitif, berpikir, dan bernalar juga tidak terabaikan. Hal ini dapat dilakukan melalui pembelajaran setiap bidang studi termasuk pembelajaran matematika.

Matematika merupakan pelajaran yang terintegrasi pada pembelajaran dari SD sampai SMA/SMK yang memiliki tujuan untuk mengembangkan kemampuan siswa dalam berpikir analisis, berpikir logis, kritis, dan sistematis. Matematika menjadi ilmu dasar untuk penerapan bidang lainnya dan bermanfaat untuk bidang ilmu lainnya dalam hal penemuan dan pengembangan (Sholihah \& Mahmudi, 2015). Matematika juga menjadi tolak ukur dalam pembuatan keputusan dari suatu gagasan yang benar atau salah (Salam \& Junta, 2012). Matematika juga dianggap sebagian besar siswa sebagai mata pelajaran kurang diminati dan dianggap sukar. Padahal, siswa seharusnya memahami bahwa dengan matematika dapat melatih kemampuan berpikirnya yang menjadi modal besar dalam menghadapi zaman yang semakin berkembang saat ini.

National Council of Teacher of Mathematics membuat rumusan terhadap kemampuan dasar yang harus dicapai dalam pembelajaran matematika yaitu penalaran matematis (reasoning), komunikasi matematis (communication), representasi matematis (representation), pemecahan masalah (problem solving) dan koneksi matematis (connection) (Rahmiati \& Fahrurrozi, 2016). Dari rekomendasi tersebut, kemampuan pemecahan masalah merupakan bagian keterampilan yang perlu diintegrasikan pada kegiatan pembelajaran matematika di sekolah. Kemampuan pemecahan masalah menurut Ramlin, Kodirun, Kadir, \& Salim (2019) terdiri dari kemampuan dalam pemahaman masalah, perancangan model matematika, penyelesaian model dan penafsiran solusi. Menurut Allo, Sudia, Kadir, \& Hasnawati (2019) juga berpendapat bahwa siswa Sekolah Menengah Pertama (SMP) efektif menguasai pembelajaran matematika manakala siswa dilatih kemampuan pemecahan masalah matematikanya. Dalam pembelajaran matematika, kemampuan pemecahan masalah digunakan untuk memudahkan proses penyelesaian masalah, penemuan solusi, dan siswa juga dengan mudah mendapatkan pengalaman belajar berdasarkan pengetahuannya (Hadi \& Radiyatul, 2014; Rasmin, Sudia \& Kadir, 2019).

Polya membagi empat tahap pengorganisasian pemecahan masalah matematika yaitu pemahaman masalah, penentuan rencana pemecahan masalah, pengerjaan sesuai rencana, pemeriksaan kembali hasil pemecahan masalah. Sejalan dengan itu, Pratiwi \& Budiarto (2014) menyatakan bahwa tahapan Polya yang sering dianggap rumit dan sukar adalah tahapan kedua dan tahap ketiga yaitu penentuan rencana pemecahan masalah dan pengerjaan sesuai rencana. Hal ini menandakan bahwa siswa perlu dilatih dengan berbagai cara untuk mendapatkan jawaban suatu masalah melalui perencanaan pemecahan masalah.

Hasil observasi awal yang dilaksanakan pada SMPN 1 Konawe Selatan memperoleh informasi bahwa siswa kurang mempunyai minat yang baik dalam mengikuti pelajaran matematika, kemampuan penyelesaian soal-soal matematika khususnya soal pemecahan masalah matematika masih tergolong rendah. Penyebab rendahnya kemampuan pemecahan masalah matematis siswa tampak pada: (1) ketika siswa diberikan masalah dalam bentuk soal cerita maka siswa kurang benar dalam mengidentifikasi apa yang diketahui, apa yang ditanyakan dan apa saja informasi yang diperlukan dalam menyelesaikan soal sehingga siswa melakukan kesalahan dalam memahami maksud dari pertanyaan soal tersebut; (2) siswa masih kurang dalam hal merencanakan penyelesaian, hal ini membuat siswa terkadang kurang tepat mengambil strategi atau langkah untuk menyelesaikan soal yang diberikan; (3) kurangnya kemampuan siswa dalam melakukan perhitungan matematika 
sehingga sulit melaksanakan rencana atau strategi yang telah dibuat; (4) kurangnya ketelitian siswa dalam menghitung hasil akhir dari pemecahan masalah dari soal yang diberikan.

Pengembangan kemampuan pemecahan masalah siswa belum sepenuhnya dilaksanakan dalam proses pembelajaran matematika di sekolah. Dari hasil observasi rendahnya kemampuan pemecahan masalah matematika siswa juga tampak pada aktivitas pembelajaran yang masih terpusat pada peran guru, dan selalu menggunakan pembelajaran konvensional sehingga dalam proses pembelajaran di kelas peranan guru begitu menonjol sehingga siswa pasif dalam belajar. Selain itu, pemberian latihan-latihan soal masih sangat kurang. Adapun soal latihan yang diberikan masih bersifat rutin dan kurang bervariasi, guru kurang melatih daya nalar siswa dalam memecahkan masalah.

Hasil tes awal kemampuan pemecahan masalah yang diberikan kepada semua siswa kelas VII SMPN 1 Konawe Selatan diperoleh rata-rata sebesar 14,31. Hal ini menunjukan bahwa kemampuan pemecahan masalah matematika siswa masih dikategorikan rendah. Mengacu pada tahapan Polya menunjukan bahwa pada tahap pemahaman masalah oleh siswa yaitu kurang mampu dalam menuliskan apa yang diketahui dan ditanyakan, sehingga siswa kesulitan dalam proses penyusunan rencana dan pelaksanaan rencana yang mana dapat dilihat pada lembar jawaban siswa terjadi banyak kesalahan dalam prosedur penyelesaian. Selanjutnya pada tahapan pemeriksaan kembali, siswa tidak dapat melakukan pemeriksaan kembali jawaban yang benar, hal ini dapat dilihat dari tidak adanya kesimpulan pada jawaban akhir.

Kemampuan pemecahan masalah matematika siswa mesti dikembangkan dalam proses pembelajaran matematika karena dengan penyelesaian suatu masalah matematika yang benar maka siswa dengan mudah memperoleh pengalaman belajar serta memanfaatkan pengetahuan dan keterampilan yang dimilikinya untuk digunakan dalam memecahkan masalah matematika. Hal ini sejalan dengan pendapat Hidayah \& Aulia (2015) bahwa seorang siswa mesti memiliki pengalaman belajar dalam memecahkan masalah sehingga siswa tersebut dapat memiliki kemampuan pemecahan masalah.

Upaya perbaikan pembelajaran untuk meningkatkan kemampuan pemecahan masalah matematis siswa, salah satunya dengan menerapkan model pembelajaran yang tepat sesuai dengan masalah, dan kondisi sekolah. Pembelajaran dengan model missouri mathematics project (MMP) dapat dipilih dan menjadi pilihan model pembelajaran yang dapat digunakan untuk meningkatkan kemampuan pemecahan masalah matematis siswa. Menurut Rais (2017) Model MMP didesain untuk membantu dan mencapai efektivitas pemanfaatan latihan-latihan dalam proses pembelajaran sehingga siswa mengalami peningkatan yang luar biasa dan terbiasa terhadap penyelesaian masalah-masalah matematika. Tujuan utama model MMP yaitu untuk mengembangkan keterampilan siswa dalam menyelesaikan persoalan matematika dengan berbagai latihan terprogram, latihan secara mandiri serta adanya pemberian pekerjaan rumah (Hidayah \& Aulia, 2015).

Pemberian banyak latihan soal kepada siswa secara tersirat dapat melatih kemampuan pemecahan masalah matematis siswa karena pembiasaan dalam menyelesaikan aneka ragam soal. Sejalan dengan itu, Wardani \& Kurniawan (2014) juga menyatakan bahwa siswa harus banyak memiliki pengalaman belajar dalam pemecahan berbagai masalah untuk mendapatkan kemampuan pemecahan masalah dalam dirinya. Siswa akan memiliki nilai lebih tinggi dalam pemecahan masalah jika banyak diberi latihan soal pemecahan masalah dibandingkan dengan siswa yang lebih sedikit diberi latihan soal pemecahan masalah.

Penelitian ini juga sejalan yang dilakukan oleh Sari, Dantes, \& Ardana (2014) dalam penelitiannya mengungkapkan bahwa jika ditinjau dari kemampuan verbalnya baik tinggi maupun rendah ditemukan bahwa secara signifikan, ada perbedaan dalam hal kemampuan untuk menyelesaikan 
masalah matematika pada kelompok belajar siswa dengan perlakuan model MMP dan pembelajaran konvensional. Hasil penelitian oleh Alba, Chotim, \& Junaedi (2013) juga mengungkapkan bahwa model MMP cukup efektif meningkatkan kemampuan pemecahan masalah matematis siswa. Pada penelitian ini memiliki batasan masalah yang lebih fokus pada pencapaian kemampuan pemecahan masalah matematis siswa melalu model pembelajaran Missouri Mathematics Project dengan sampel penelitian siswa kelas VII SMPN 1 Konawe Selatan.

Model MMP yang ditemukan melalui penelitian ini mengarahkan siswa pada latihan-latihan terprogram, meliputi pengulangan (review), pengembangan, latihan terprogram/belajar kooperatif, belajar mandiri (seatwork), dan penugasan (homework) guna mendapatkan peningkatan kemampuan pemecahan masalah. Menurut Hati, Sapri, \& Wasidi (2019) bahwa siswa yang diajar dengan model MMP akan memiliki sikap kemandirian belajar yang tinggi sehingga akan berdampak pada pencapaian prestasi belajar yang lebih baik dibanding siswa yang mempunyai kemandirian rendah. Tujuan dari penelitian yaitu untuk mengkaji model pembelajaran Missouri Mathematics Project berpengaruh terhadap kemampuan pemecahan masalah matematis siswa.

\section{METODE}

Penelitian ini merupakan penelitian quasi experimental. Penelitian ini dilakukan pada SMP Negeri 1 Konawe Selatan tahun 2020 semester genap dengan materi pelajaran aritmetika sosial. Sampel yang digunakan dalam penelitian ini sebanyak dua kelompok kelas yaitu satu kelompok sebagai kelas ekperimen dan satu kelompok sebagai kelas kontrol. Teknik penentuan sampel dengan purposive sampling yaitu mengambil dua kelompok kelas perlakuan yang memiliki nilai rata-rata dan varians tes kemampuan awal yang hampir sama. Dari lima kelas yang ada, terpilih kelas VIIC dan kelas VIIE. Pemilihan kelompok kelas eksperimen dan kelompok kelas kontrol, dilakukan secara random. Hasilnya, kelas VIIC sebagai kelompok kelas eksperimen dan kelas VIIE sebagai kelompok kelas kontrol. Penelitian ini menggunakan desain Posttest-Only Control Group Design dengan masingmasing kelompok kelas mendapatkan perlakuan yang berbeda yaitu pada kelompok kelas eksperimen siswa diberikan pembelajaran dengan model MMP dan kelompok kelas kontrol siswa diberikan pembelajaran dengan model pembelajaran langsung.

Pengumpulan data yang digunakan dalam penelitian ini yaitu lembar aktivitas pembelajaran dan soal tes kemampuan pemecahan masalah matematis siswa. Lembar aktivitas pembelajaran digunakan untuk mengobservasi setiap aktivitas pembelajaran baik yang dilakukan guru maupun siswa sedangkan tes kemampuan pemecahan masalah digunakan untuk mengukur tingkat perkembangan kemampuan pemecahan masalah matematis siswa yang berbentuk uraian tertulis.

Data yang diperoleh dalam penelitian ini dianalisis menggunak statistik deskriptif dan statistik inferensial. Analisis statistika deskriptif disajikan dalam bentuk persentase dan kategorisasi, mean, standar deviasi, nilai maksimum, dan nilai minimum. Untuk pengkategorian aktivitas guru dan siswa mengacu pada kategorisasi yang dibuat oleh Purnamasari \& Himmawati (2017) seperti pada Tabel 1. Aktivitas belajar yang dilakukan guru dan siswa dikatakan aktif apabila memenuhi kategori minimal berada pada rentang baik.

Tabel 1. Kategorisasi Aktivitas Guru dan Siswa

\begin{tabular}{ccc}
\hline No & Rentang Nilai (\%) & Kategori \\
\hline 1 & $X<60$ & Sangat Kurang \\
\hline 2 & $60 \leq X<70$ & Kurang \\
\hline 3 & $70 \leq X<80$ & Cukup \\
\hline 4 & $80 \leq X<90$ & Baik \\
\hline 5 & $X \geq 90$ & Sangat Baik \\
\hline
\end{tabular}


Statistik inferensial dalam penelitian ini digunakan untuk menguji hipotesis penelitian. Namun, terlebih dahulu dilakukan uji prasyarat yaitu uji normalitas dan uji homogenitas. Data dikatakan berdistibusi normal jika nilai sig. $>\alpha=0,05$ dan data tidak berdistribusi normal jika nilai sig. $\leq$ $\alpha=0,05$. Begitu pula, kelompok data dikatakan homogen jika nilai sig. $>\alpha=0,05$, dan kelompok data dikatakan tidak homogen jika nilai sig. $\leq \alpha=0,05$. Pengujian hipotesis menggunakan uji independent sample t-test untuk menganalisis ada tidaknya perbedaan signifikan rata-rata kemampuan pemecahan masalah matematis antara kelompok siswa yang diberi pembelajaran model MMP dengan kelompok siswa yang diberi pembelajaran model konvensional. Kriteria pengujian hipotesis yaitu jika nilai $\frac{\text { Sig.(2-tailed) }}{2} \leq \alpha=0,05$, maka kemampuan pemecahan masalah matematis siswa pada kelompok siswa yang diberi pembelajaran model MMP lebih baik dari kelompok siswa yang diberi pembelajaran dengan model konvensional. Begitu juga sebaliknya, jika nilai $\frac{\text { Sig.(2-tailed) }}{2}>\alpha=0,05$, maka kemampuan pemecahan masalah matematis siswa pada kelompok siswa yang diberi pembelajaran model MMP tidak lebih baik atau sama dengan kelompok siswa yang diberi pembelajaran dengan model konvensional.

\section{HASIL DAN PEMBAHASAN}

Penelitian ini dilakukan sebanyak empat kali pertemuan yang dilanjutkan satu kali pertemuan untuk mengambil data post-test berupa data kemampuan pemecahan masalah matematis siswa. Untuk data hasil observasi dilakukan ketika proses pelaksanaan pembelajaran berlangsung. Hasil observasi aktivitas pembelajaran dengan model MMP baik dilakukan oleh siswa dan guru tampak pada Tabel 2 berikut.

Tabel 2. Aktivitas Guru dan Siswa dalam Pelaksanaan Pembelajaran dengan Model MMP

\begin{tabular}{lcccccc}
\hline \multirow{2}{*}{ Pertemuan } & \multicolumn{3}{c}{ Guru } & \multicolumn{3}{c}{ Siswa } \\
\cline { 2 - 6 } & Skor & Persentase & Kategori & Skor & Persentase & Kategori \\
\hline Pertama & 68 & $85 \%$ & Baik & 71 & $74 \%$ & Cukup \\
\hline Kedua & 71 & $88,7 \%$ & Baik & 77 & $80,2 \%$ & Baik \\
\hline Ketiga & 78 & $97,5 \%$ & Sangat Baik & 82 & $85,3 \%$ & Baik \\
\hline Keempat & 78 & $97,5 \%$ & Sangat Baik & 92 & $95,8 \%$ & Sangat Baik \\
\hline Rata-Rata & 73,75 & $92,18 \%$ & Sangat Baik & 80,50 & $83,83 \%$ & Baik \\
\hline
\end{tabular}

Berdasarkan hasil pada Tabel 2 tampak bahwa pada pertemuan pertama yakni guru masih melakukan penyesuaian terhadap model pembelajaran MMP dan perlu mengenal karakteristik siswa, sehingga terdapat tahapan model MMP yang terlupakan untuk dilaksanakan. Misalnya, pada tahap mereview materi yang berkaitan, mengelompokkan peserta didik secara heterogen, dan penyampaian materi yang dipelajari untuk pertemuan selanjutnya. Pada pertemuan kedua, guru telah melakukan refleksi terhadap pertemuan pertama, namun, pemberian penjelasan materi dan pemberian kesempatan kepada siswa untuk mengamati sumber belajar masih kurang, dikarenakan adanya keterbatasan waktu. Pada pertemuan ketiga dan keempat, guru sudah dapat mengontrol keadaan kelas dan sudah terbiasa menggunakan model MMP saat pelaksanaan pembelajaran. Berdasarkan hasil observasi aktivitas belajar tersebut, tampak bahwa pengelolaan dan pelaksanaan pembelajaran oleh guru menggunakan model pembelajaran MMP sudah terlaksana dengan baik.

Aktivitas siswa selama proses pembelajaran melalui model MMP yaitu pada pertemuan pertama, siswa berada pada kondisi penyesuaian diri terhadap aktivitas guru dan model pembelajaran MMP, sehingga banyak aktivitas pembelajaran tidak dilakukan siswa misalnya, dalam memperhatikan pemberian apersepsi, motivasi, penyampaian kompetensi inti, kesempatan bertanya, serta siswa kurang aktif dalam melaksanakan diskusi dan siswa tidak mengagendakan proyek yang akan 
dipelajari pada pertemuan selanjutnya. Bahkan ketika salah satu kelompok diminta untuk memaparkan jawabannya, siswa kurang percaya diri atau terkesan malu-malu. Pada pertemuan kedua, siswa dengan mudah menyesuaikan dan beradaptasi dengan proses pembelajaran yang diterapkan, sehingga beberapa tahap yang tidak dilakukan di pertemuan pertama tercapai di pertemuan kedua. Namun, untuk tahap bertanya siswa masih tidak berani untuk mengajukan pertanyaan. Pertemuan ketiga sampai keempat, aktivitas belajar siswa mulai terdapat peningkatan jika ditinjau dari keterlaksanaan pada pertemuan sebelumnya. Pada pertemuan ini, siswa dengan mudah menemukan penyelesaian masalah dari soal yang diberikan dan siswa mulai terbiasa dengan belajar kelompok dengan pembelajaran model MMP. Siswa juga mulai terlihat aktif dalam kelompoknya dan cukup antusias mengajukan pertanyaan dan mengikuti dengan seksama proses pembelajaran.

Pada kelas kontrol, siswa diajar dengan model pembelajaran langsung dengan guru yang mengajar pada kelas kontrol juga sama orangnya yang mengajar di kelas eksperimen. Kesamaan guru dalam mengajar pada kedua kelompok kelas untuk menyamakan keterampilan dan kesamaan persepsi siswa terhadap guru sehingga keberhasilan penelitian ini bukan disebabkan karena perbedaaan keterampilan guru tetapi karena ada pemberian perlakuan model pembelajaran yang berbeda pada kedua kelompok kelas. Pada kelas eksperimen diajar dengan model MMP yang memiliki lima langkah pembelajaran yaitu review, pengembangan, latihan terkontrol, latihan mandiri, dan penugasan atau pemberian PR. Pada kelas kontrol diajar dengan model pembelajaran langsung dengan tahapan meliputi penyampaian tujuan pembelajaran, mendemonstrasikan pengetahuan, mengajukan pertanyaan ke siswa, mengecek pemahaman dan memberikan umpan balik, memberikan kesempatan untuk latihan mandiri.

Hasil analisis deskriptif nilai post-test kemampuan pemecahan masalah siswa pada kelompok yang diberi pembelajaran model MMP dengan pembelajaran model konvensional tampak pada Tabel 3.

Tabel 3. Deskripsi Kemampuan Pemecahan Masalah Matematis Siswa

\begin{tabular}{ccc}
\hline Statistik Deskriptif & Model MMP & Model Konvensional \\
\hline Mean & 71.60 & 35.48 \\
\hline Std. Deviation & 16.06592 & 14.19779 \\
\hline Minimum & 30.00 & 12.50 \\
\hline Maximum & 95.00 & 70.00 \\
\hline
\end{tabular}

Berdasarkan hasil pada Tabel 3 terlihat bahwa rata-rata kemampuan pemecahan masalah siswa pada kelompok kelas yang diberikan pembelajaran model MMP lebih tinggi dibandingkan dengan kelompok kelas yang diberikan pembelajaran model konvensional. Hasil penelitian ini menandakan bahwa adanya pembelajaran dengan model MMP menjadikan kemampuan pemecahan masalah matematis siswa lebih beragam dibandingkan dengan pembelajaran model konvensional. Hal lainnya juga tampak pada salah satu jawaban siswa yang diberikan pembelajaran model MMP dengan hasil memiliki langkah penyelesaian permasalahan yang cukup baik. 


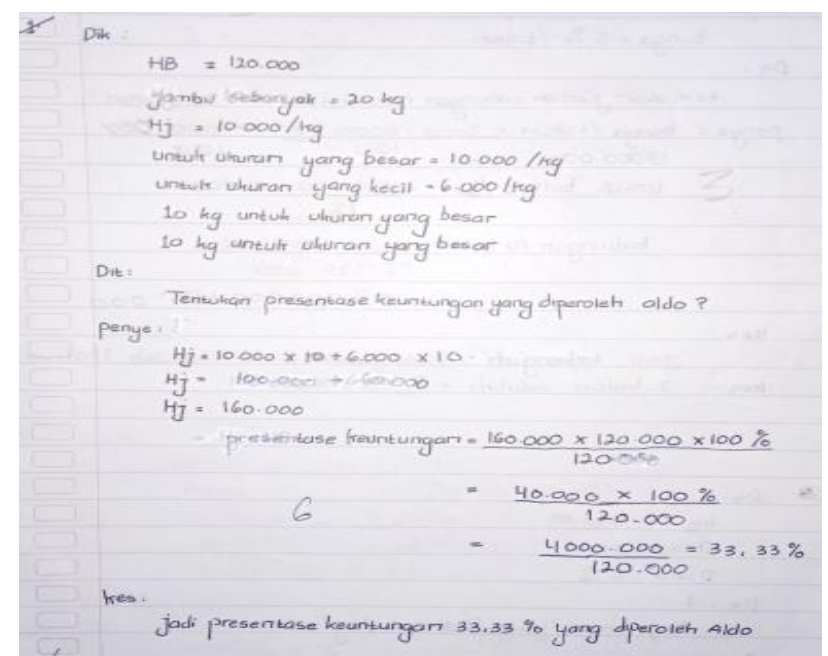

Gambar 1. Hasil Jawaban yang diberikan pembelajaran Model MMP

Hasil dari Gambar 1 tampak bahwa kemampuan pemecahan masalah matematis siswa yang diberikan pembelajaran model MMP mampu memenuhi langkah-langkah pemecahan masalah degan benar seperti menuliskan apa yang diketahui dan ditanyakan secara tepat, menyusun perencenaan penyelesaian tertulis secara runtut, dan penyelesaiannya memperoleh hasil akhir dengan benar. Selanjutnya, sebelum melakukan uji hipotesis didahului dengan melakukan uji normalitas data dan uji homogenitas data sebagai prasyarat uji hipotesis dengan hasil seperti yang tercantum pada Tabel 4.

Tabel 4. Hasil Uji Normalitas dan Uji Homogenitas Kemampuan Pemecahan Masalah Siswa

\begin{tabular}{ccccc}
\hline \multirow{2}{*}{ Kelas } & \multicolumn{2}{c}{ Uji Normalitas } & \multicolumn{2}{c}{ Uji Homogenitas } \\
\cline { 2 - 3 } & Sig. & \multicolumn{1}{c}{ Keputusan } & Sig. & Keputusan \\
\hline Kelas Eksperiman & 0,291 & Berdistribusi Normal & \multirow{2}{*}{0,272} & \multirow{2}{*}{ Homogen } \\
\hline Kelas Kontrol & 0,563 & Berdistribusi Normal & & \\
\hline
\end{tabular}

Hasil pada Tabel 4 menunjukkan bahwa data kemampuan pemecahan masalah matematis siswa baik yang diberikan pembelajaran model MMP maupun dengan model konvensional memiliki distribusi normal. Sedangkan sebaran data kemampuan pemecahan masalah pada kedua kelas pembelajaran yang diberikan model MMP dan model konvensional memiliki varians yang homogen. Pengujian hipotesis digunakan uji-t sampel independen yang yang tampak pada Tabel 5.

Tabel 5. Hasil Uji Hipotesis

\begin{tabular}{ccc}
\hline $\boldsymbol{t}$ thitung & $\frac{\boldsymbol{S i g}(\mathbf{2}-\text { tailed })}{\mathbf{2}}$ & Keputusan \\
\hline 9,159 & 0,00 & Tolak $\mathrm{H}_{0}$ \\
\hline
\end{tabular}

Hasil uji-t sampel independen yang diperoleh pada Tabel 5 menunjukkan bahwa nilai $\mathrm{t}_{\text {hitung }}$ adalah $9,159>\mathfrak{t}_{\text {tabel }}\left(\right.$ dengan $\left.\mathfrak{t}_{(0,05,29+30-2)}=1,672\right)$ dan nilai $\frac{\text { Sig (2-tailed })}{2}$ adalah $0,00<\alpha$ maka tolak $\mathrm{H}_{0}$. Dengan ditolaknya $\mathrm{H}_{0}$, maka dapat dikatakan bahwa kemampuan pemecahan masalah matematis siswa yang diberikan pembelajaran model MMP lebih baik dari model konvensional.

Hasil penelitian menunjukkan bahwa terdapat pengaruh yang signifikan pelaksaaan pembelajaran dengan model MMP terhadap kemampuan pemecahan masalah matematis siswa. Hal ini tidak 
terlepas dari efek pelaksaaan model MMP dalam pembelajaran matematika. Pelaksanaan pembelajaran dengan model MMP memiliki 5 langkah pembelajaran yaitu review, pengembangan, latihan terkontrol, latihan mandiri, dan penugasan atau pemberian PR. Pada tahap review, guru membantu siswa mempersiapkan diri untuk menerima materi baru dan mengingatkan kembali materi sebelumnya yang telah diajarkan terkait topik materi yang akan diterima siswa. Pada tahap pengembangan terdapat kegiatan penyampaian gagasan baru, pengembangan konsep matematika sebelumnya, pemberian rangsangan belajar untuk memusatkan perhatian siswa, konstruksi pengetahuan matematika dengan kehidupan nyata, terjadi diskusi siswa dan guru secara interaktif, dan adanya kombinasi latihan terkontrol.

Pada langkah latihan terkontrol, diatur belajar siswa secara berkelompok sebanyak 4-5 orang untuk menyelesaikan permasalahan pada lembar kerja peserta didik (LKPD). Konten yang tersaji pada LKPD dirancang untuk membuat siswa terbiasa dengan tahapan-tahapan dalam menyelesaikan masalah. Guru mengontrol kelompok belajar siswa yang mengalami miskonsepsi dengan memberikan bantuan penjelasan materi untuk perbaikan dan mengambil kesimpulan jawaban yang benar. Pelaksanaan, dan peningkatan serta latihan terprogram dapat saling membantu satu sama lainnya. Guru harus memberikan tangung jawab dalam kelompok belajar siswa dan pemberian ganjaran secara individu. Pada tahap kerja mandiri, siswa diberikan latihan-latihan dan menyelesaikannya secara mandiri pula. Kerja mandiri juga dimaksudkan untuk mengetahui perkembangan pemahaman siswa secara individu mengenai materi yang disajikan guru pada tahap pengembangan serta tahap latihan terkontrol. Pada tahap penugasan/PR, siswa diberikan tugas rumah untuk diselesaikan secara mandiri. Pemberian tugas terkait materi pelajaran pertemuan berikutnya. Hasil dari rangkaian kegiatan pembelajaran dengan tahapan model MMP sangat menekankan kepada siswa untuk menyelesaikan latihan soal dalam proses pembelajaran baik secara kooperatif maupun mandiri, sehingga materi pelajaran dapat dipahami dengan baik dan dapat membiasakan siswa dalam meningkatkan kemampuan pemecahan masalah matematika.

Keberhasilan pelaksanaan pembelajaran juga melibatkan peranan guru dan siswa yang aktif selama proses pembelajaran berlangsung. Adanya model MMP membuat guru dan siswa semakin ikut berpartisipasi dalam kegiatan pembelajaran, dan terjadi proses pembelajaran yang cukup interaktif. Hal ini ditunjukkan dengan aktivitas pembelajaran baik oleh guru dan siswa pada setiap pertemuannya semakin meningkat persentasenya sehingga guru memiliki aktivitas pembelajaran dengan kategori sangat baik dan siswa memiliki aktivitas pembelajaran dengan kategori baik. Wardani \& Kurnia (2014) dalam penelitian mengungkapkan bahwa seseorang yang secara kontinu melakukan sesuatu akan menjadi kebiasaanya sehingga akan berdampak pada hasil pencapaian belajarnya khususnya kemampuan pemecahan masalah.

Adanya rata-rata kemampuan pemecahan masalah matematis siswa yang diberikan pembelajaran model MMP lebih tinggi nilainya dari pada siswa yang diberikan pembelajaran model konvensional. Hal ini menandakan bahwa pembelajaran model MMP secara signifikan berpengaruh terhadap kemampuan pemecahan masalah matematis siswa jika dibandingkan dengan pembelajaran model konvensional. Hal ini karena efek dari pemberian treatment pembelajaran dengan model MMP yang membuat siswa lebih aktif berdiskusi dalam kelompok, dan siswa saling berbagi informasi dalam memecahkan masalah. Sejalan dengan itu, Gunawan et al. (2013) dalam penelitiannya mengungkapkan bahwa kemampuan pemecahan masalah siswa dapat lebih baik jika diberi banyak latihan. Putra \& Fitriyani (2018) dalam penelitiannya mengungkapkan bahwa kemampuan pemecahan matematis siswa dapat ditingkatkan melalui model pembelajaran MMP. 
Tingkat keberhasilan siswa belajar dengan pembelajaran model MMP dalam tiap soal lebih tinggi dari pada siswa belajar dengan pembelajaran model konvensional. Hal ini diakibatkan karena dalam proses pembelajaran kelas yang diberi pembelajaran model MMP lebih sering mendapatkan latihanlatihan soal yang dapat memicu keterbiasaan siswa dalam menyelesaikan suatu masalah. Banyaknya latihan soal yang diberikan guru pada tahap latihan terkontrol dan mandiri merupakan langkah baru untuk meningkatkan kemampuan siswa dalam menyelesaikan masalah yang mana siswa memiliki pengalaman lebih banyak dalam menyelesaikan suatu masalah. Fauziah \& Sukasno (2015) mengungkapkan siswa yang diberikan latihan soal sebanyak tiga kali, yaitu soal pertama diselesaikan secara bersama-sama soal kedua dikerjakan secara mandiri (seatwork), dan soal ketiga penugasan yang diselesaikan di rumah dapat meningkatkan kemampuan yang diharapkan. Marliani (2015) juga mengungkapkan bahwa pemilihan model pembelajaran yang tepat dan efektif akan menjadikan siswa lebih aktif dalam pelaksanaan pembelajaran dan model MMP dapat menjadi alternatif model pembelajaran yang cocok.

\section{KESIMPULAN DAN SARAN}

Kesimpulan dari hasil penelitian ini yaitu secara signifikan terdapat pengaruh pembelajaran dengan model MMP terhadap kemampuan pemecahan masalah matematis siswa yang ditunjukkan dengan capaian (1) aktivitas pembelajaran dengan model MMP yang dilakukan oleh guru maupun siswa masuk pada kategori sangat baik dan baik; (2) rata-rata kemampuan pemecahan masalah matematis siswa dengan pembelajaran model MMP yaitu 71,60 lebih tinggi nilanya dari rata-rata dengan model pembelajaran konvensional yaitu 35,48; (3) kemampuan pemecahan masalah matematis siswa yang diberikan pembelajaran dengan model MMP lebih baik dari siswa yang diajar model pembelajaran konvensional. Saran yang dapat dikemukakan yaitu diantaranya: (a) perlunya upaya guru untuk melakukan pembiasaan kepada siswa terhadap penyelesaian soal-soal kemampuan pemecahanan masalahnya; (b) model missouri mathematics project dapat diterapkan untuk meteri lainnya selain aritmetika sosial.

\section{DAFTAR PUSTAKA}

Alba, F. M., Chotim, M., \& Junaedi. (2013). Keefektifan Model Pembelajaran Generatif dan MMP Terhadap Kemampuan Pemecahan Masalah. Kreano: Jurnal Matematika Kreatif-Inovatif, 4(2), 131-137. https://doi.org/10.15294/kreano.v4i2.3136

Allo, D. P., Sudia, M., Kadir, \& Hasnawati. (2019). Penerapan Model Pembelajaran Problem Based Learning Setting Kelompok Untuk Meningkatkan Kemampuan Pemecahan Masalah Matematis Siswa di SMP Swasta Antam Pomalaa. Jurnal Pendidikan Matematika, 10(1), 19-30. http://dx.doi.org/10.36709/jpm.v10i1.5641

Fauziah, A., \& Sukasno. (2015). Pengaruh Model Missouri Mathematics Project (MMP) Terhadap Kemampuan Pemahaman dan Pemecahan Masalah Matematika Siswa SMA N I Lubuklinggau. Infinity: Jurnal Ilmiah Program Studi Matematika STKIP Siliwangi Bandung, 4(1), 10-21.

Gunawan, G., Fitriana, U., Kushendri, K., Fatimah, F., Mustika, C., \& Hidayat, W. (2019). Kemampuan Pemecahan Masalah Matematis Siswa SMP Melalui Pemberian Perlakuan Pembelajaran. Journal on Education, 1(3), 1-8.

Hadi, S., \& Radiyatul. (2014). Metode Pemecahan Masalah Menurut Polya untuk Mengembangkan Kemampuan Siswa dalam Pemecahan Masalah Matematis di Sekolah Menengah Pertama. EDU-MAT: Jurnal Pendidikan Matematika, 2(1), 53-61. http://dx.doi.org/10.20527/edumat.v2i1.603

Hati, R., Sapri, J., \& Wasidi. (2019). Pengaruh Model Pembelajaran Missouri Mathematics Project Dan Kemandirian Belajar Terhadap Prestasi Siswa. DIADIK : Jurnal Ilmiah Teknologi Pendidikan, 8(1), 34-47.

Hidayah, A., \& Aulia, I. (2015). Penerapan Model Pembelajaran Missouri Mathematics Project (MMP) Terhadap Kemampuan Pemecahan Masalah Siswa di SMP. EDU-MAT: Jurnal Pendidikan Matematika, 3(1), 49-58. http://dx.doi.org/10.20527/edumat.v3i1.629 
Marliani, N. (2015). Peningkatan Kemampuan Berpikir Kreatif Matematis Siswa Melalui Model Pembelajaran Missouri Mathematics Project (MMP). Formatif: Jurnal Ilmiah Pendidikan MIPA, 5(1), 14-25. http://dx.doi.org/10.30998/formatif.v5i1.166

Pratiwi, S. D., \& Budiarto, M. T. (2014). Profil Metakognisi Siswa SMP dalam Memecahkan Masalah Matematika Ditinjau dari Kemampuan Matematika Siswa. MATHEdunesa, 3(2), 179186.

Putra, S. S., \& Fitriyani, H. (2018). Pembelajaran Matematika Dengan Model Missouri Mathematics Project untuk Meningkatkan Kemampuan Pemecahan Masalah Matematika Siswa SMP. Prosiding Seminar Nasional Pendidikan, Sains dan Teknologi Fakultas Matematika dan Ilmu Pengetahuan Alam Universitas Muhammadiyah Semarang,312-319.

Rahmiati, \& Fahrurrozi. (2016). Pengaruh Pembelajaran Missouri Mathematics Project (MMP) Terhdap Kemampuan Pemecahan Masalah Matematika. Jurnal Pendidikan Matematika, 4(2), 145-156. http://dx.doi.org/10.22342/jpm.10.2.3634.75-86

Rais, D. (2017). Pengembangan Perangkat Pembelajaran Matematika Berbasis Missouri Mathematics Project untuk Meningkatkan Kemampuan Komunikasi Matematis Peserta Didik Kelas X SMA/MA. JNPM (Jurnal Nasional Pendidikan Matematika), 1(2), 189-205. http://dx.doi.org/10.33603/jnpm.v1i2.473

Ramlin, Kodirun, Kadir, \& Salim. (2019). Perbandingan Kemampuan Literasi Matematis Siswa SMP Negeri 8 Kendari antara Yang Diajar Dengan Model Pembelajaran Inkuiri Terbimbing dan Yang Diajar Dengan Model Pembelajaran Konvensional. Jurnal Pendidikan Matematika, 10(1), 1-11. http://dx.doi.org/10.36709/jpm.v10i1.5639

Rasmin, Sudia, M., \& Kadir. (2019). Pengaruh Pembelajaran Problem Posing terhadap Kemampuan Pemecahan Masalah Matematis Siswa. Jurnal Pembelajaran Berpikir Matematika, 3(2), 85 95. http://dx.doi.org/10.33772/jpbm.v3i2.5736

Salam, M. \& Junta, A. (2012). Perbedaan Hasil Belajar Matematika Ditinjau dari Model Pembelajaran Kooperatif Tipe TSTS dan tipe STAD. Jurnal Pendidikan Matematika, 3(2), 187200. http://dx.doi.org/10.36709/jpm.v3i2.1996

Sari, F., Nurhayati, \& Salim. (2019). Meningkatkan Kreativitas dalam Membentuk Objek Melalui Kardus Geometri. Jurnal Riset Golden Age PAUD UHO, 2(2), 144-148. http://dx.doi.org/10.36709/jrga.v2i2.8364

Sari, N. R. U, Dantes, N., \& Ardana, I. M. (2014). Pengaruh Model Pembelajaran Missouri Mathematics Project terhadap Kemampuan Menyelesaikan Soal Cerita Matematika Ditinjau dari Kemampuan Verbal. e-Journal Program Pascasarjana Universitas Pendidikan Ganesha Program Studi Pendidikan Dasar, 4(2), 311-322.

Sholihah, D. A., dan Mahmudi, A. (2015). Keefektifan Experiential Learning Pembelajaran Matematika MTs Materi Bangun Ruang Sisi Datar. Jurnal Riset Pendidikan Matematika, 2(2), 174-185. https://doi.org/10.21831/jrpm.v2i2.7332

Wardani, A. K., \& Kurniawan, L. (2014). Kemampuan Pemecahan Masalah Berdasarkan Perbedaan Jenis Kelamin. Jurnal Pendidikan Matematika STKIP PGRI Sidoarjo, 2(1), 99-108. 